\title{
SHAMAN, PSYCHOANALYST OR OBSTETRICIAN: A CRITICAL READING OF CLAUDE LÉVI-STRAUSS' ESSAY “THE EFFICIENCY OF SYMBOLS"
}

\author{
Staffan Mjönes
}

\begin{abstract}
This article intends to clarify the obstetric, medical-psychological and ethnological credibility of a well-known essay in structural anthropology. Claude Lévi-Strauss claims that it is possible to heal a person with an acute, life-threatening, physical, medical condition, in this case a complicated delivery, with purely psychological or magical methods. His reasoning is based on an incomplete source as well as on a grave anatomical misunderstanding. An obstetric analysis of the complete source furthermore shows that the medicine man or shaman uses a combination of a manual intervention, drug treatment and psychological influence. Lévi-Strauss' claim must therefore be refuted. The empirical basis is also insufficient for Lévi-Strauss' far-reaching conclusions on the topography of the human mind, the function of the subconscious and the comparison between psychoanalysis and shamanism. The medicine man is described by Lévi-Strauss as a "noble savage". However, Lévi-Strauss also points out the importance of the psychological support of the patient in a valuable way.
\end{abstract}

Key words: birth, cosmology, disease, medical anthropology, obstetrics, shamanism, structuralism, traditional medicine

\section{INTRODUCTION}

Claude Lévi-Strauss' Structural Anthropology, published in English in 1963, was a breakthrough for structuralist thought in anthropology and for Claude Lévi-Strauss himself as a researcher. The Effectiveness of Symbols is the title of a well-known essay in this collection (Lévi-Strauss 1977). It consists of the analysis of a song sung during deliveries in the Cuna tribe in Panama. A shaman, which is the term Lévi-Strauss uses, or medicine man, the term used by the translators of the song, a traditional healer, treats and heals a woman in severe parturition difficulties. However, Lévi-Strauss' essay is based on an incomplete source, i.e. Lévi-Strauss refers only to the first two thirds of the whole song. The essay moreover shows other gaps and mistakes in the obstetric and ethnographic interpretation and brings forth two very controversial 
conclusions: the first interpretation concerns the possibility to heal an acutely ill person with a very severe physical condition through psychological and magical means only, and the other the construction and function of the human mind, notably an innate, unconscious function sorting all impressions of the senses according to a few structuring laws. As structuralism remains an important influence in the humanities and social sciences it is important to critically review the basis for Lévi-Strauss' conclusions.

\section{ACQUISITION OF THE SONG}

As Erland Nordenskiöld (1877-1932), professor of ethnography, head of the Gothenburg ethnographical museum travelled during 1927 in Panama among the Cuna people he got to know Néle de Kalunda, a man of great learning in the history and traditional ways of his people. Néle dictated a long narrative with this content to his secretary who travelled to Gothenburg with the material. Nordenskiolld and the secretary translated and analyzed the text. Nordenskiöld noted, in his commentary in a passage on the Cuna religion, that a spiritual power named $M u$ had something to do with childbirth. He writes (Nordenskiöld 1938):

It would be of the greatest interest to get hold of a record of muu igala, the song which is sung under the bed of the woman who is bearing a child.

The name of the man who came to record just that song was Guillermo Hayans, a Cuna Indian born 1906 and a trusted informant during decades to the Gothenburg group of ethnographers. He, as well, had studied with Néle de Kalunda, for ten years, and served as his secretary, knew him well and sent several ethnographic reports to the researchers in Gothenburg, He also occupied official posts among the Cuna in his part of Panama. Among his other reports is the record of a song on the treatment of mental disease, published by the group in Gothenburg (Holmer \& Wassén 1958). Wassén met him on a journey to Panama in 1935 and asked him to provide a song about $M u$, which Hayans subsequently did, having interviewed Huauquine, an old man instructed in the song (Holmer \& Wassén 1953).

\section{PUBLICATIONS OF THE SONG}

The first part of the song was published in 1947 as Mu-Igala or the Way of Muu: A Medicine Song from the Cunas of Panama, by Nils Holmer, a researcher in comparative linguistics and Henry Wassén, an ethnographer and expert on 
South American Indian tribes, and especially their use of herbs and drugs (Holmer \& Wassén 1947). The volume consists of the song in the Cuna language, collected and partly translated into Spanish by Guillermo Hayans; a translation from the Cuna text into English by Holmer, linguistic comments by him and ethnographic comments by Wassén. This is the version that forms the basis for Claude Lévi-Strauss in all his publications of the essay, in French or English, in the original form or as reprints of Structural Anthropology, and in anthologies.

The Swedish researchers had published the song in 1947 believing the version to be complete. However, in 1952 Hayans sent a letter, explaining that World War II had made correspondence between Panama and Europe impossible and enclosing the final third of the song as well as a picture writing for the whole song, together with some other material. Holmer and Wassén made a new publication in a year with the full song, the whole picture writing and linguistic and ethnographic comments. The title this time was The Complete Mu-Igala in Picture Writing. A Native Record of a Cuna Medicine Song (Holmer \& Wassén 1953).

\section{PUBLICATIONS OF THE ESSAY}

Lévi-Strauss' first publication of the essay was the 1949 article in a French journal of the history of religions (Lévi-Strauss 1949), two years after the song was published in Sweden. The next publication was in French as well, as part of Anthropologie structurale in 1958 (Lévi-Strauss 1958); followed by Structural Anthropology in1963 (Lévi-Strauss 1963) in English with several reprints and in at least one anthology (Lessa \& Vogt 1979). Hence, as his great work Structural Anthropology which uses the incomplete version of the song was first published in French and in English, five and ten years had elapsed since the complete version of the song was published in 1953.

\section{PRESENTATION OF THE COMPLETE SONG}

Nordenskiöld specifically asked for stories and ideas about a female being called $M u$, thought among the Cunas to live in women's wombs. She is considered to be the agent that gives form to the child during pregnancy (Holmer \& Wassén 1953). She is sometimes also called the soul of the uterus and is mentioned both as Muu and Muu Puklip. 
All parts of the body such as the stomach and the heart have their own soul. Together, these souls form an immaterial and invisible second body. In a healthy person all the souls of the body are in their correct position and work together in harmony. Niga purbalele denotes "the soul of life" (Holmer \& Wassén 1953) or an individual, physical power of life.

The song is organized in 657 short verses consisting of one or two text lines. There is a parallel description of the course of events in picture writing. It consists partially of a series of scenes, like a comic strip but some pictures may have phonetic meaning rather than a content meaning. The pictures are in colour but presented in black and white in the publication, except the last page which is rendered in the original colours (Fig. 1).

\section{Part one and two (verses 1-535)}

In the beginning of the song we meet a midwife giving aid to a woman in labour, but something is wrong:

1. The (sick) woman speaks to the midwife: "I can feel (in me) that I am being dressed in the hot garments of disease."

2. The midwife answers her (sick woman): "You can feel (in you) that you are being dressed in the hot garment of the disease I also hear you (say)."

3. The midwife addresses her (woman): "For how many days have you suffered the bad garments of the disease?"

4. The woman answers her (midwife): "For two days I have suffered the hot garment of the disease."

5. The midwife answers her (sick woman): "For two days you can feel that you are being dressed in the hot garment of disease, I also hear."

7. The midwife turns around in the hut.

8. The midwife looks for some beads.

9. The midwife turns around (in order to leave).

10. The midwife puts one foot in front of the other.

11. The midwife touches the ground with her foot.

12. The midwife puts her other foot forward (?).

13. The midwife pushes open the door of the hut; the door of the hut creaks. 
14. The midwife goes out, outside she stands looking all in consternation.

15. The midwife puts one foot in front of the other.

The midwife notes that the delivery situation is critical and that they both need help. She goes to find the medicine man in the same village:

54. The medicine man puts down his foot on the path to the woman's hut.

55. The medicine man puts forth his other foot on the path to the woman's hut.

56. The medicine man is about to enter the (sick) woman's door.

57. A small golden seat is put under the hammock of the (sick) woman.

58. The medicine man sits down on the small golden seat.

59. Under the woman's hammock there is put a brazier, the brazier being concave.

60. The medicine man looks for cocoa beans.

61. The medicine man puts the cocoa beans into the hollow of the brazier

62. The cocoa beans are being burned.

63. The cocoa beans are healing.

Note the slow, low-keyed, repetitious, rhythmic start of the text and furthermore that the boundaries of the doors are marked and every step noted. The tempo will be increased into furioso in the course of labour.

The medicine man presents figures from specific types of wood. Such figures are called nuchus. The figures represent tutelary spirits or nelegan (sing. nele) and the shaman is to lead them in a magical sense through the Muu-Igala or Muu's way, the vagina, to her abode, the uterus. The wooden figures are however not inserted into the vagina.

67. Nele Tionuchunana and her children strengthen their garments, nele Tionuchunana and her children strengthen their golden hats.

71. "Under the hammock of the (sick) woman I raise you up, nelegan."

72. They rise along the extremity of Muu Puklip's road. 
A multitude of spirits aggregate at the vaginal opening, ready for battle. For most spirits we are given their names only in the Cuna language without further description of their background and function.

An important clinical description follows:

84. (The medicine man says): "The sick woman lies in the hammock in front of you."

85. She is lying amidst the white garments, her white garments are budding like a flower.

86. The (sick) woman's body lies weak.

87. When they light up (along) Muu's way, it runs over with exudations all like blood.

88. Her exudations drip down below the hammock, all red (like the $i k k w i$ tree).

89. The inner white garment extends toward the bosom of the earth.

90. Into the middle of the of the woman's white garment a human being descends.

91. The woman sits gasping toward the East, she sits with open knees, her exudations run over, all like blood.

97. (The woman answers): "My eyesight is straying, it is asleep on Muu Puklip's path."

98. It is Muu Puklip who has come to me. She wants to take my niga purbalele for good.

The patient is in a critical condition. She is bleeding and exuding amniotic fluid. The whitish foetal membranes and umbilical cord hang out. Inside these white structures, somewhere, there is a human being. The woman is very sick, so sick that she is losing her eye-sight. She realizes the gravity of the situation and her interpretation is that $M u u$, the female principle in her womb has taken control of her body and is threatening her life. The medicine man garnishes the wooden figures with beads, necklaces and other pieces of magical equipment. The medicine man starts to carve more nuchus:

146. "It is for the benefit of the human race that I carve your bodies with a little sharp knife from the strangers, that I mould your bodies, that I ... your bodies, that I transform your bodies, that I create your bodies, all into the appearance of human beings". 
The wooden figures are vitalized, given a soul, by the medicine man. He also stays in rapport with them, advising and encouraging them in a dialogue throughout the delivery:

235. The medicine man advises his nelegan: "As for Muu Puklip's stronghold, it is not difficult to see at once, since you are invisible, you are becoming nele's, you will perform things by seeing (?)."

236. "The medicine man gives you a living soul, the medicine man changes for you (your) soul, all like replicas (?), all like twin figures."

237. "The medicine man plants niga into you, the medicine man changes your niga, all replicas, all like twin figures."

Then the nelegan march in into the vagina, along Muu's way, in one single line or file towards the uterus. They are invisible but are able to see within the woman's body. The small wooden figures are not introduced into the vagina. They march past the Low Mountain, the High, pointed mountain, into the centre of the Flat Mountain and arrive in Muu's whirlpool and her house and meet with many malevolent and dangerous spirits:

239. The nelegan go balancing on top of the hammock, they go upward like nusupane.

240. The nelegan put good eyes into the (sick) woman.

241. The nelegan set out, the nelegan march in a single file along Muu's road, as far as the Low Mountain.

242. The nelegan set out etc., as far as the Low Mountain,

243. The nelegan set out etc., as far as the High (Pointed) Mountain,

247. The nelegan set out, etc., into the centre of the Flat Mountain.

253. In Muи Puklip's whirlpool there are alligators dwelling.

254. Uncle Alligator Towili moves about with bulging eyes, he moves bending his body, emerging from the water, he moves with his body variegated, he moves wriggling his tail.

258. The body glistens smooth, the flippers glisten. The flippers conquer the place, the flippers push aside the place (?), the flippers drag (?) the place in foam. 
287. Toward the last of the doors Muu's animal approaches, 288. The black animal is tied with its iron chain, the iron chain rattles, 289. The points of its tongue are hanging down, the tongue is hanging out, the saliva is dripping, the saliva is foaming, the tail is wagging.

290. Muu's black tiger is tied with its iron chain, etc.

296. Muu's cat is opening the points of its claws, is closing the points of its claws,

297. It lies with the points of the claws standing out like needles, its claws are coming out,

298. The points of the claws are tearing, all like blood, all red.

299. The nelegan are taking advice, without intermission.

These monsters are vividly and grotesquely shown in the picture writing. Muu's abode is full of hanging threads and curtains, as well:

306. From the top of Muu Puklip's house threads of cloth are attached. 307. Muu's threads of cloth are changing into gold all about Muu Puklip's house.

308. The rainbow-coloured (?) curtains flutter,

309. The rainbow-coloured (?) curtains are wavering.

310. About Muu Puklip's house cobweb (silk) curtains flutter, silk curtains waver,

And so on.

330. (The medicine man) calls those who are to break the cloth threads.

331. He calls those who are to cut the cloth threads.

332. Toward the sunrise he calls the Lords of the wood-boring insects.

333. They come to cut the threads.

In this spooky room Muu asks the intruding nelegan why they have come. Their answer is that they have come to save and liberate the sick woman's niga purbalele, her "soul of life" All through the march and the entry into the abode, the borders of the vagina and the uterine opening are explicitly marked. 
The nelegan search the house marching four by four. They also collect the souls living in each and every part of the body and reassemble the soul of life.

388. The nelegan march as far as the very end of Muu Puklip's fourth room, the nelegan step along, four and four the nelegan march ...,

400. (The nelegan) search for the niga purbalele of the (sick) woman, without leaving a single nook of Muu Puklip's house.

435. Into her body they put again (her) niga purbalele.

436. Into her body they put again (her) heart soul.

437. Into her body they put again (her) lung soul.

438. Into her body they put again (her) bone soul.

And so on.

The woman is not yet healed. The healer sees the need for more medication and some kind of surgical intervention.

448. "The diseases are not healed at once, the diseases are increasing, 449. The body becomes weak."

450. "Dweller on the mountain, dweller on the top of the mountain, your plants are drying on the ground."

451. He (the medicine man) calls on the Nele Upina Wakasip.

452. He goes to find the plants (?), he brandishes the plants, and balances with the plants.

453. The medicine man approaches the opening of $M u u$, he approaches like nusupane, he moves like nusupane.

454. He is going to wipe (?) the inner place all dry, completely drying the inner place.

The two last verses imply that the medicine man actually touches the woman by entering the vagina with his hand, like a penis (nusupane); they furthermore imply that he is going to cleanse and dry the uterine cavity.

The tutelary spirits fear that Muu may see that the vagina is open and try to escape. That would be a catastrophe as the woman's fertility would be lost forever. They block the vagina with sticks and a net: 
529. If Muu sees that the way in the (sick) woman is open (?) the nelegan will rise.

530. They strike with the sticks and they are holding their sticks in a line.

531. The nelegan swing their golden net, they put the golden net above the place in front of the house (?).

So far the two first thirds of the song have been presented, the only parts with which Lévi-Strauss concerns himself. At this point he regards the delivery as completed. This is surprising as it has not been explicitly said that a child has been born or stillborn, or that the woman has recovered or succumbed. On the contrary, the song states clearly that she is not healed, that her life and ability to beget children again are in danger and that the shaman increases his efforts to help her. But Lévi-Strauss states explicitly that the woman has been healed and by psychological and magical means only: “...a purely psychological treatment, for the shaman does not touch the body of the sick woman and administers no remedy." (Lévi-Strauss 1977).

\section{“The missing part", part three (verses 536-657)}

In the following section, the last third of the song will be presented; the one that so surprisingly arrived in Gothenburg after World War II.

Again it is clear that the woman is not healed. The medicine man seems disturbed and tries to find fibres and exsiccating drugs to stop the bleeding. He grates bark for remedies.

536. The medicine man stands turning around in the house,

537. The medicine man rises to look for fibres,

538. He rises to look for desiccating medicines,

539. The medicine man begins to grate the bark of the medicinal plant with the grating stone.

The woman continues to bleed and exude amniotic fluid.

540. Her exudations are descending, her exudations are dripping down. The medicine man continues his search for remedies:

550. He rises to look for the fibres of haemostatic (?) medicines, The midwife says that the woman is succumbing: 


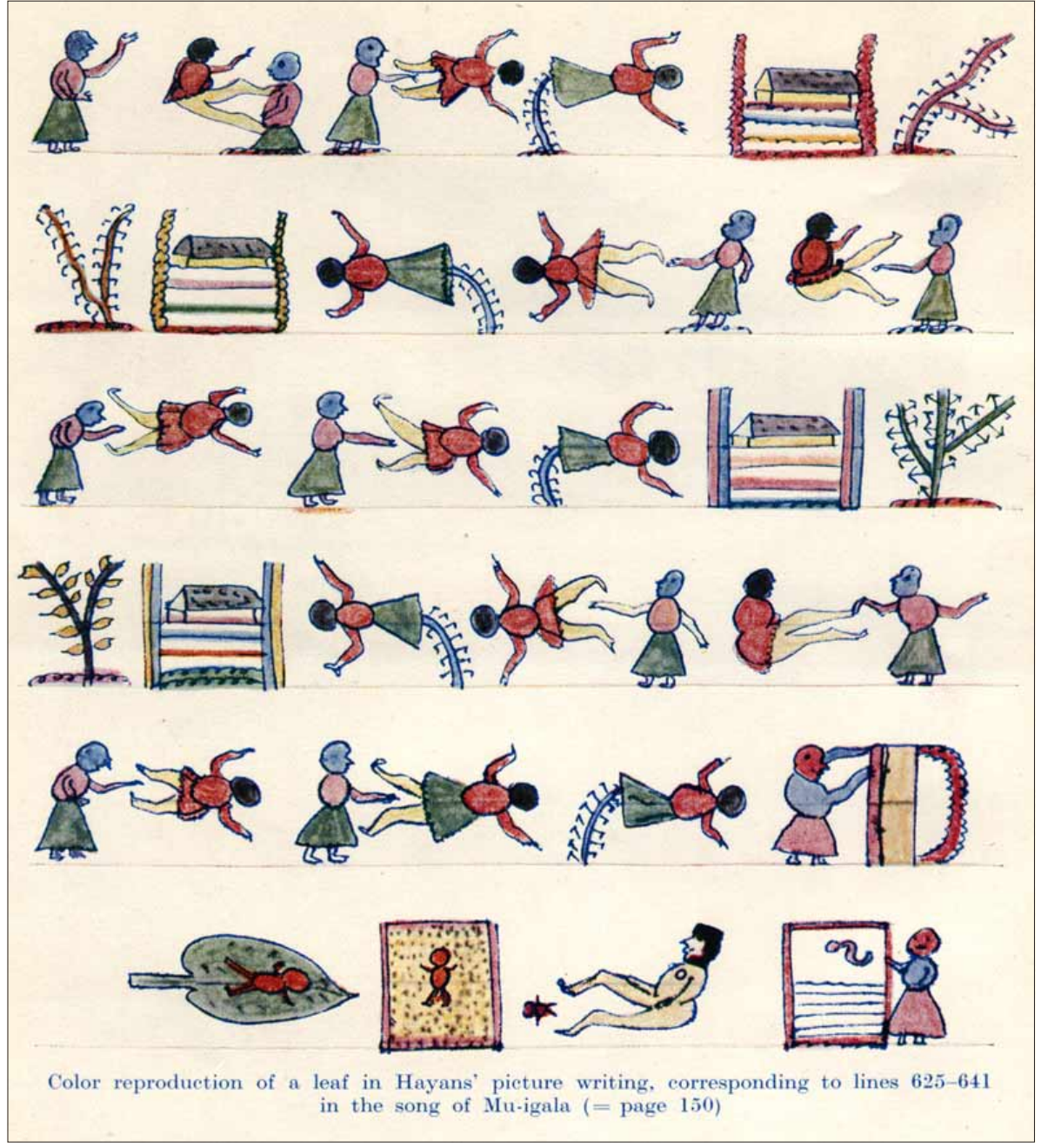

Figure 1. The last page of the picture writing in The complete $\mathrm{Mu}$-Igala in picture writing. It should be read from the upside down and from left to right; right to left etc. starting from the left in the top row and ending at the left in the bottom row. It shows the medicine man (or possibly the midwife) standing at work with the ailing woman lying down. Note the bluish-white umbilical cord hanging out between the woman's legs. In the last row the umbilical cord is disposed of; the woman sits undressed on the ground, the child is lying on the ground, then transferred to a leaf. The small red object to the left of the undressed woman is probably the placenta. (Reprinted with permission) 
556. "Since I am a midwife, I can perceive that the disease is getting the better of me."

In repeated, exciting sequences it is described how the medicine man goes on a fantasy journey in the forest to seek remedies. He paddles on a river and finds various herbs, most importantly lianas from which he cuts parts. He finds a remedy for the bleeding.

598. "The medicine man approaches the blood-staunching (?) liana, ..."

The midwife proclaims the battle to be lost and that she is giving up:

602. The woman calls out, being the midwife of the sick woman: "It (the disease) has won over me, I can see."

Then, however, the course is dramatically improved. The medicine man returns to the woman's hut and administers the drugs which take effect. The narrative tempo is markedly increased.

605. The medicine lianas are hanging within reach, the lianas of the pisep-plant are hanging within reach:

606. They are closing in on Muu's water containers, because they are medicines,

607. They are embracing Muu's water containers, ...

The midwife (or the sick woman) notes the "golden entrails", probably the placenta:

626. The woman sits (on her hammock) regarding the golden entrails, she sits hauling (?) the golden entrails, she sits pulling the golden entrails, because she is a chief woman.

627. Toward the East, she calls on the nele's of the masikia-plants:

628. They are looking after the golden entrails for the sick woman's midwife.

A spirit opens the "principal gate", the uterine or vaginal opening and the child descends to the ground. Blocked material, probably clotted blood, gushes out at the same time and the "golden calabash", most probably the placenta, tumbles to the ground. The poetic tone is one of great relief:

639. Olotak(k)intili raises the principal gate, opens the principal gate, the child descends, she brings the child down. 
640. Into the bosom of the earth the child is descending,

641. Into the bosom of the pale urwa-leaf, the child is descending,

642. It reddens the whole pale urwa-leaf.

643. Toward the East a river breaks through the place,

644. A Golden River breaks through and the golden calabash comes tumbling down along;

645. The diseases are carried off (by its flow) afar towards its mouth, 646. The alligators are carried off by (its flow), afar towards its mouth,

647. The trunks of driftwood are carried off (by its flow), afar towards its mouth.

648. A Silver River breaks through the place, the golden calabash comes tumbling down along;

The situation in all its pain and impending tragedy is at last being solved and in a wonderful way. The end is gloriously triumphant, yet moving:

654. Toward the East the Golden Wind blows;

655. The child comes descending, the child has come descending.

656. Toward the East the Silver Wind is blowing;

657. The child comes descending, a child has come descending.

\section{DISCUSSION}

Lévi-Strauss claims (i) that the woman is healed by psychological-magical means only, without any physical intervention and (ii) that this result is achieved through a mechanism that is principally the same as the Abreaction of Freudian psychoanalysis, the reaction taking place in a parallel manner in the mind and the body but elicited by psychological influence only, mediated through an unconscious operator that generates binary oppositions from all stimuli that reach the brain. Both conclusions have to be challenged.

\section{The point in time for healing}

The question, whether Lévi-Strauss has demonstrated that the ailing woman is healed without physical intervention, must be answered in the negative. The version of the song he uses does not reach the point where the healing is 
complete as the text used is unfinished. Not only does Lévi-Strauss' interpretation omit that a continued critical clinical state is at hand, it positively contradicts it, as demonstrated in verses 448-449, quoted above. He also fails to mention what happened to the child who is curiously absent all through the essay.

\section{An anatomical error}

In the text he uses, Lévi-Strauss makes a grave anatomical misinterpretation. Verses 86-91 describe an ailing woman with white structures hanging out from between her legs and in the structures, somewhere, a human being is seen. The obvious explanation is that the foetal membranes have been broken but are still wrapped about the child which is visible outside the vagina and that the umbilical cord hangs out. These anatomical structures are always white with a bluish tinge (Sleep 1993a; Sleep 1993b). Lévi-Strauss, possibly misled by Wassén, sees them as the inside of the vagina. But that structure is deep purple in the latter stage of a delivery! The white structures are described as "inner", which makes perfect sense as they have resided with the child inside the uterus. Any uncertainty on this point disappears when consulting the last part of the picture writing where a bluish-white umbilical cord hangs out between the legs of the woman in several pictures (Fig. 1).

\section{Physical management and drug intervention}

From verses 453-454 it is clear that the medicine man enters the vagina and the uterus with his hand, like nusupane, a penis, to cleanse and dry the cavity, perhaps with some absorbent material. Verses 450-452, still in the incomplete text, show that the shaman intends to use herbal remedies. In the third part, it is furthermore mentioned that he looks for fibres and desiccating medicines (verses 537-539); he searches the fibres of "haemostatic (?)" medicines (verse 550 ) to prevent bleeding and so on. The skilled botanist Wassén could identify several of the herbs in the text. One of them, Ficus glabrata contains an active substance, chemically close to the proteolytic agent papain, which could, for example, dissolve blood-clots (Samuelsson 1992). Hence, there is strong evidence the medicine man uses drugs and other remedies. 


\section{Physical and magic-psychological treatment}

From "the outside", the etic and modern point of view, we witness a suffering woman aided by a midwife who seeks the help of a traditional healer for her patient's ailment. The woman lies in a hammock, bleeding, very sick. The child is outside the womb and the vagina, swept in the foetal membranes and with the umbilical cord still attached to the placenta. It seems that the placenta is not expelled spontaneously from the uterus. The medicine man talks to the woman, burns incense, administers drugs and enters the vagina with his hand, following the umbilical cord, frees the placenta which slides out together with debris, blood-clots and amniotic fluid. He wipes the uterine cavity dry and packs it with fibres as absorbents. The umbilical cord is cut and the child put on a palm leaf.

From "the inside", the emic and traditional point of view, we see an ailing woman for whom the anatomical details, the pain and the blood etc. are just as real but who experiences her condition as a consequence of the capture by Muu of her "life soul". A battle is launched between $M u u$ and her allies on one side and tutelary spirits led by the healer on the other. Muu is defeated, but not killed, the woman regains her power of life; the uterine organ soul retakes its position in the hierarchy of organs, order is restored and the woman and the child are saved.

Where the modern observer sees an anatomical landscape, the woman and the medicine man see a mythological one with many details. In the mythological landscape borders are sharply marked as limes: the hut doors of the woman and the medicine man, the anatomical orifices and so on (Gennep 1960). The mountains that the nelegan pass on their way match landmarks in the skeleton palpable from inside the vagina. They walk into the Flat Mountain, (verse 247) which could very well be the flattened uterine cervix into which the umbilical cord leads. V. Turner (1974) showed that an object may well have a practical use and, at the same time, for instance in a ceremony, serve as one or even several shifting symbols.

\section{A manual intervention}

In the etic world an important act of the medicine man would be called manual removal of placenta (Sleep 1993b). A well-known obstetric complication is that the placenta adheres to the uterine wall even when the child has come out. The uterus starts to contract around it but cannot contract completely; the uterine mucosa continues to bleed and is open to infection. If the placenta is 
not removed the patient will most probably die from blood loss. Doctors, during antiquity and many folk practitioners of midwifery, had/have practical knowledge and skill in obstetrics (Akenzua \& Akpovi et al. 1981; Negussie 1988). The manoeuvre was described in the second century by the Roman gynaecologist Soranos (Soranos 2001).

For the intervention manual removal of the placenta, one hand of the practitioner is formed into a cone around the umbilical cord, with the four fingers turned against the practitioner and the thumb pointing towards the patient. The other hand stabilizes the placenta from the outside pressing it downward into the abdomen. Slowly and carefully the hand follows the cord into the uterine cavity where the hand is turned. The four fingers are spread and the placenta gently separated from the uterine wall by shearing movements. Then the placenta slides or is gently pulled out and the uterus can continue to contract. The bleeding stops and the mucosa is less exposed to infection.

The text supports the thought that the medicine man used this method (or possibly the midwife on his instructions). The tutelary spirits are commanded to walk in a single line into the vagina and the uterus (verse 241). They are passing different mountains (verses 242-243) and walking into the Flat Mountain (verse 247), probably the flattened uterine cervix, they march four by four in $M u$ u's abode, in other words the uterine cavity (verse 388); the medicine man moves into the woman like a penis (verse 453); when the course turns to the better "the golden entrails", probably the placenta, slide out (verse 626). Modern practitioners, who have performed the manoeuvre of the manual removal of the placenta, describe a strange sense of the material in the placenta and uterine wall, reminiscent of decaying wood and the text speaks of the Lords of the wood-boring insects who come to help (verse 332).

Lévi-Stauss states that the medicine man never touches the woman. $\mathrm{He}$ gives no support for this notion. One group among the Cuna traditional health practitioners do work without manual contact with their patient but even they may have diverse practical positions and functions making a manual intervention quite possible in this case (Holmer \& Wassén 1953).

In the emic world the same manoeuvre is performed but here the tutelary spirits, represented by the fingers of the medicine man go into Muu's way, the vagina, and walk in a single file into Muu's whirlpool, the uterine cavity, where the pain and the difficulties are represented by horrible animals.

The concepts of both worldviews in this context are valid and coherent, each on its own premises. Both may be applied for practical use and can be 
transferred as knowledge to a new practitioner. By talking to the woman, reading or singing for her the healer establishes contact and trust and gives emotional support.

\section{Drugs and remedies}

Not only does the medicine man make a manual removal of the placenta, he wipes the uterine cavity dry, probably stopping bleeding by packing it with absorbent material (verse 537). He administers drugs as well, one of which is stated to be blood-staunching, even if we do not know exactly what it is and one that could dissolve adherences and blood-clots. Herbs are sometimes described in terms of tutelary spirits.

\section{Salutogenesis and the sense of coherence}

Although Lévi-Strauss lacks support for his comparison between psychoanalysis and shamanism there is no doubt that the medicine man helps the woman by explaining and confirming, at some level, what they both think to be the cause of her ailment, explaining to her the development and what is done to help her, all in terms and a language understandable to the two of them. He also gives emotional support and wins her confidence. Their rapport fits well with the modern concepts of the medical sociologist Aaron Antontovsky (1988). He uses the term the sense of coherence as an important factor in health, for salutogenesis:

"The sense of coherence is a global orientation that expresses the extent to which one has a pervasive, enduring though dynamic feeling of confidence that (1) the stimuli deriving from one's internal and external environments in the course of living are structured, predictable, and explicable; (2) the resources are available to one to meet the demands posed by these stimuli; and (3) these demands are challenges, worthy of investment and engagement."

The medicine man refers to a worldview and uses terminology he has in common with the woman - a reminder for modern practitioners of health care to adapt language and medical terms to the needs of the patient for emergencies as well as long term treatments. Hence, the medicine man works with several methods and on several levels at the same time: manual intervention; drug treatment and psychological influence. 


\section{"The noble savage"}

The medicine man seems to be portrayed as "the noble savage". Lévi-Strauss, at the same time, endows him with supernatural healing powers and denies him the understanding of uncomplicated mechanical and pharmacological connections.

\section{Shamanism compared to psychoanalysis}

It is valuable that Lévi-Strauss points out how the medicine man gives psychological and emotional support to the ailing woman. The medicine man, at some level of language, activates the cosmological concept of the world of the woman by speaking to her in mythological terms. By listening, a psychoanalyst may help the modern patient with no mythological belief or understanding to build his/her own myth. In both cases, Lévi-Strauss says that the shaman and the analyst reach very deep levels of the human psyche, so deep that a neuropsychological sorting automaton, dividing all impressions into binary oppositions, is postulated. From that centre, through different stages, an Abreaction, that is both psychological and physiological, could allegedly be activated. This implies a jump between mind and matter, a jump for which Lévi-Strauss offers no empirical support. Furthermore, it is very difficult to follow his reasoning as the woman is not healed by psychological means only. Even if a psychological and physiological healing occurred in parallel, it would be no proof of causality (Neu 1975). The idea is unrealistic, viewed with practical eyes. The tempo of a psychoanalysis of a physically healthy individual with a psychological problem is measured in years; the tempo of a delivery in hours and minutes. This woman's psyche is clouded by blood loss and pain. The idea of a physiology that the medicine man and woman have in common is about a "phantasy physiology", not a real one (Neu 1975).

\section{FINAL REFLECTION}

A birth is a biological and human situation of great ethnographic concern with its connections to a worldview and myths. Lévi-Strauss presents a song where a traditional healer helps a woman in childbirth but his presentation is incomplete. He overstates the power of psychology in the treatment of an acute, life threatening physical condition and cannot demonstrate that shamanistic heal- 
ing and psychoanalysis are essentially the same process. The complete song is a unique document of thinking, skill and imagination in traditional medicine with its cosmologic implications, a beautiful drama of the highest interest for ethnographers and general readers as well as for health care practitioners.

\section{ACKNOWLEDGEMENTS}

Thanks are due to Professor Åsa Ljungström, PH.D., Department of Humanities, Mid Sweden University for ethnological advice and personal support throughout the work and Katarina Gregersdotter, PH.D., University of Umeå, for language correction.

\section{REFERENCES}

Akenzua, Gregory I. \& Akpovi, Samuel U. et al. 1981. Maternal and Child Care in Rural Areas: the Role of Traditional Birth Attendants in Bendel State of Nigeria. Journal of Tropical Pediatrics, Vol. 27, pp. 210-214.

Antonovsky, Aaron 1988. Unraveling the mystery of health. How people manage stress and stay well. San Francisco: Jossey-Bass, p. 19.

Gennep, Arnold van 1960. The rites of passage. Chicago: The University of Chicago Press.

Holmer, Nils M. \& Wassén, S. Henry 1947. Mu-Igala or the Way of Muu. A Medicine Song from the Cunas of Panama. Göteborg: Ethnographical Museum.

Holmer, Nils M. \& Wassén, S. Henry 1953. The complete Mu-Igala in picture writing. A Native Record of a Cuna Indian Song. Etnologiska Studier 21. Göteborg.

Holmer, Nils M. \& Wassén, S. Henry, 1958. Nia-Ikala. Canto magico para curar la locura. Etnologiska Studier 23. Göteborg.

Lévi-Strauss, Claude 1949. L'Éfficacité symbolique. Revue de L'Histoire des Religions. Vol. 135, No. 1, pp. 5-27. Paris: Libraire Plon.

Lévi-Strauss, Claude 1958. Anthropologie structurale. Paris: Librairie Plon.

Lévi-Strauss, Claude 1977. The Effectiveness of Symbols. In: Structural Anthropology. Harmondsworth: Penguin books.

Lévi-Strauss, Claude 1979. The Effectiveness of Symbols. In: W. Lessa \& E. Vogt (eds.) Reader in Comparative Religion. An Anthropological Approach. New York: Harper \& Row.

Negussie, Birgit 1988. Traditional Wisdom and Modern Development. A case study of traditional perinatal knowledge among elderly women in Southern Shewa, Ethiopia. In: Studies in Comparative and International Education, No. 13. Stockholm: University of Stockholm. 
Neu, Jerome 1975. Lévi-Strauss on shamanism. Man. (New series: The Journal of the Royal Anthropological Institute), Vol. 10, No. 2, pp. 285-292.

Nordenskiöld, Erland 1938. An Historical and Ethnological Survey of the Cuna Indians, in Collaboration with the Cuna Indian, Ruben Pérez Kantule. In: H. Wassén (ed.) Comparative Ethnographical Studies, Vol. 10. Göteborg: Göteborg Museum.

Samuelsson, Gunnar 1992. Drugs of natural origin. A textbook of pharmacognosy. Södertälje: Swedish Pharmaceutical Press.

Sleep, Jennifer 1993a. Physiology and management of the second stage of labour. In: V. Bennet \& L. Brown (eds.) Myles' textbook for midwives. Edinburgh: Churchill Livingstone. 